Revue d'études américaines. American Studies Journal

\title{
Confronting Race Head-on in 12 Years a Slave (Steve McQueen, 2013): Redefining the Contours of the Classic Biopic?
}

\section{Anne-Marie Paquet-Deyris}

\section{(2) OpenEdition}

Journals

Electronic version

URL: https://journals.openedition.org/transatlantica/11593

DOI: 10.4000/transatlantica.11593

ISSN: $1765-2766$

Publisher

Association française d'Etudes Américaines (AFEA)

Electronic reference

Anne-Marie Paquet-Deyris, "Confronting Race Head-on in 12 Years a Slave (Steve McQueen, 2013):

Redefining the Contours of the Classic Biopic?", Transatlantica [Online], 1 | 2018, Online since 05

September 2019, connection on 02 February 2023. URL: http://journals.openedition.org/

transatlantica/11593 ; DOI: https://doi.org/10.4000/transatlantica.11593

This text was automatically generated on 2 February 2023

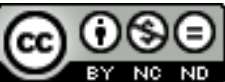

Creative Commons - Attribution-NonCommercial-NoDerivatives 4.0 International - CC BY-NC-ND 4.0 https://creativecommons.org/licenses/by-nc-nd/4.0/ 


\title{
Confronting Race Head-on in 12 Years a Slave (Steve McQueen, 2013): Redefining the Contours of the Classic Biopic?
}

\author{
Anne-Marie Paquet-Deyris
}

1 During the Obama years, the issue of race seemed to dissolve into the so-called "postracial" era in the media. For critics such as H. Roy Kaplan in The Myth of Post-Racial America: Searching for Equality in the Age of Materialism (2011) and David J. Leonard and Lisa A. Guerrero in African Americans on Television: Race-ing for Ratings (2013), however, such colorblindness led to the bypassing of any direct confrontation with the persistent problems linked to race in contemporary American society.

2 In his critically acclaimed 2013 cinematic release 12 Years a Slave, Steve McQueen circumvents the "great white narrative" by addressing race "head-on" instead of metaphorically, writing every character within their own racial background. As in Solomon Northup's 1853 Twelve Years a Slave, black characters are not removed from their own histories; instead, they are shaped and defined by them. To what extent, then, does the film distinctly voice racial concerns and tensions and provide representational spaces on screen in a nuanced and reflective manner? How does it-if indeed it does-subvert the characteristic black slave/character and white master/hero dynamic and embrace a wide variety of black stories and perspectives? By reconsidering the classic biopic/historical film, I will examine how the movie relocates America's problems with race at the very heart of the national debate and offers a "post-post-racial" screen model that directly confronts race history.

3 In The Black Image in the White Mind: Media and Race in America, Robert M. Entman and Andrew Rojecki suggest there is

a new goal (or end) for media operations in the realm of race: encouraging audiences and media producers alike to become more critically self-aware as they deal with the culture's racial signals. Such activity would serve not only the social interest in racial comity, but the media's long-term economic interests as well. And 
it would set the stage for an eventual cessation-an end in the other sense-to color consciousness, for arrival at the time, however far off, when "race" no longer holds meaning for media producers and their audiences.

Building on Benedict Anderson's work on "imagined communities," they insist that "[t]oday, the same processes operate: common identification is shaped by mediated images of who constitutes one's own people and nation" (Entman and Rojecki 205).

4 To what extent does 12 Years a Slave rebuild and extend this imagined community by inscribing the experience of slavery on screen? Does McQueen's treatment of the historical movie/biopic change the way in which the race factor has been addressed so far in American cinema and is it a socially subversive intervention?

\section{One hundred years of silence}

5 At the time 12 Years a Slave was released, quite a few critical voices had already emphasized the impossibility of squaring "post-racialism" with contemporary material realities in the United States. The main comments had to do with the misrepresentation of the black experience on screen-including in movies where the lead actors were black-and with the lingering stereotypical treatment of racialized bodies. Even some movies and TV shows like Quentin Tarantino's 2012 Django Unchained or Veena Sud's 2018 Seven Seconds and Dan Fogelman's 2016 This Is Us, reputed for championing a representational space for black bodies, critics claimed, were structured around a white male narrative arc to further the plot. ${ }^{1}$

In 1984, American photographer and director Gordon Parks had already fictionalized Solomon Northup's narrative of enslavement, adapting it for television under the title Solomon Northup's Odyssey. But his protagonist (interpreted by Avery Brooks) very much fell into the "hypermasculine categor[y] of the 'Heroic Slave' as famously invented by Frederick Douglass" (Tillet 360). His representation of Northup bordered on the exceptional. By figuring the past, Parks felt compelled to construct an idealized heroic figure, thus bypassing the rules and conventions of the biopic. If we consider that the biopic's fundamental tenets are to "[depict] the life of a historical person, past or present" (Custen 5) and provide a certain degree of realism, objectivity, and verifiability, then this earlier adaptation of Twelve Years a Slave is by no means a classic biopic. Neither is 12 Years a Slave. Northup only recently became a "famous" public figure, largely thanks to McQueen's film. As McQueen emphasized in numerous interviews, Twelve Years a Slave was seldom read even in African American literature classes and was not as well-known as slave narratives such as The Interesting Narrative of the Life of Olaudah Equiano (1789) and Narrative of the Life of Frederick Douglass, an American Slave (1845) (Roy 13-14). That 12 Years a Slave should relate the life of a real nineteenthcentury free black man kidnapped into slavery is the main aspect that links it to the category of the biopic. Yet McQueen's goal has little to do with “[the] genre's charge, which [...] is to enter the biographical subject into the pantheon of cultural mythology, one way or another, and to show why he or she belongs there" (Bingham 10). As a violinist who was well integrated in Saratoga's local community and provided for his family, Northup was in many ways an ordinary citizen, a status that stands in sharp contrast with the usual paradigm of heroization which is emblematic of the classic biopic. McQueen goes against the grain as he re-visions the biopic in a manner similar to Dennis Bingham's in his 2010 Whose Lives Are They Anyway? The Biopic as Contemporary 
Film Genre. For Bingham, the genre needs to be reevaluated as a complex, fast-evolving, impure category which can actually invent new ways of looking at the person and rendering his or her experience in some unadulterated way, making it virtually palpable.

7 McQueen uses a fractured storyline, artfully weaving past and present. He deploys flashbacks within flashbacks to stage the centrality of the body, which is both his artistic staple and the way in which independent film producers and early African American directors like Oscar Micheaux fought the relegation of black characters to the margins of the frame and society. ${ }^{2}$ In a conversation with Harvard scholar Henry Louis Gates, Jr., he talks about the use of the body in his work as follows:

All we have is our bodies. That's our vessel. But what I am interested in is not necessarily that, but the subjects that are around it. [...] The story is about the environment, and how individuals have to make sense of it, how we locate the self in events. The body is used, but it's a byproduct of the bigger question. (Gates 191)

With the potential "too-much-ness" of unrelenting scenes of violence (Gates 191), he voices what Michael Taussig calls "the public secret [...] which is generally known, but cannot be articulated" (Taussig 5). Countering the current effort to deliberately avoid the awareness of race, he flaunts every possible racial signal so as to "do [...] justice" to "what took place in those times" (Gates 192).

In her introduction to Harriet Jacobs's 1861 Incidents in the Life of a Slave Girl, white abolitionist Lydia Maria Child similarly commented on this tale of sexual abuse by insisting that even though "[t]his peculiar phase of slavery has generally been kept veiled [...] the public ought to be made acquainted with its monstrous features, and I willingly take the responsibility of presenting them with the veil withdrawn" (Andrews and Gates 747-748). In her essay "The Site of Memory," Toni Morrison suggested as well that her mission was to "rip that veil drawn over "proceedings too terrible to relate" and to expose and articulate the unspeakable in her fiction (Zinsser 191). Possibly inscribing it on screen for the first time in such a graphic way, this is also what McQueen resolutely does. The straight cut from the joyful dinner scene in Washington, DC, to the silence and darkness of the cell where Northup (Chiwetel Ejiofor) has been locked up materializes on screen "the dark night of slavery." When Douglass uses the phrase in his Narrative, he foregrounds the taming process at work and its devastating effect on body and soul:

I was somewhat unmanageable when I first went there, but a few months of this discipline tamed me. Mr. Covey succeeded in breaking me. I was broken in body, soul, and spirit. My natural elasticity was crushed, my intellect languished, the disposition to read departed, the cheerful spark that lingered about my eye died; the dark night of slavery closed in upon me; and behold a man transformed into a brute! (Andrews and Gates 324)

The breaking process starts all the more savagely for Northup as the contrast with his previous circumstances is total. The camera captures him having dinner at a fine restaurant with his white employers and giving a toast to celebrate his successful and profitable tour. Refined classical background music is heard before the straight cut to the dark basement where he finds himself in shackles.

9 The brutal shift in atmosphere is thus effected thanks to a straight cut to a dark room and an absence of sounds, until Northup regains consciousness and is startled by the rattle of his chains. A metaphorical and actual "cage" of light visually enacts the dehumanizing process of slavery already at work. Just as rebel leader Joseph Cinqué 
(Djimon Hounsou) wrenches off the nail of his manacles in Steven Spielberg's Amistad (1997), Northup tries to free himself from his chains. His uncomprehending stare at his own irons enacts the unthinkable and compels the viewer to face a world in which freedom has become an irrelevant concept.

In the source autobiography, Northup describes his terror in the following terms:

From that moment I was insensible. How long I remained in that conditionwhether only that night, or many days and nights-I do not know; but when consciousness returned, I found myself alone, in utter darkness, and in chains. (Northup 37-38)

After the in medias res beginning, the complex flashback structure of this sequence where at least three different time levels are interwoven allows for an even greater focus on the individual, which is one of the characteristics of the biopic genre. This is paradoxical as it takes place precisely at a time when Northup is denied the status of independent free human being. From this beautifully lit sequence and chiaroscuro shot on, the blurred frontiers between the black and white communities become more and more demarcated.

Even though McQueen was working within the received conventions of the biopic while adapting a slave narrative, his representation of the black body met with harsh critical comments. The most common charge had to do with the misrepresentation of the black experience on screen and the stereotypical treatment of racial bodies mostly shown as suffering bodies. Historian Margaret Washington, for instance, insisted on the prevalent representation of black people as mere victimized bodies in the film:

There is no slave community in the movie. Instead, Platt [Northup's slave name] is a silent observer of enslaved people who assert no agency, no struggle, and do not have a culture or a sense of morality. They are beaten-down victims. Only Platt wants "to live"; others are content to "survive." However, in the actual narrative Platt describes how he fits into a slave community. He recounts for the reader the personalities, individualities and temperaments of enslaved people, and he relates their culture. [...] In the movie, slaves are cotton-picking, cane-cutting stick figures; recipients of white violence; even sexually wanton. (Miller 322-323)

Ironically, some of McQueen's early shots register on screen as snapshots of slavery, strange blended families mostly presented as surface images that catch but a fragment of a complex experience.

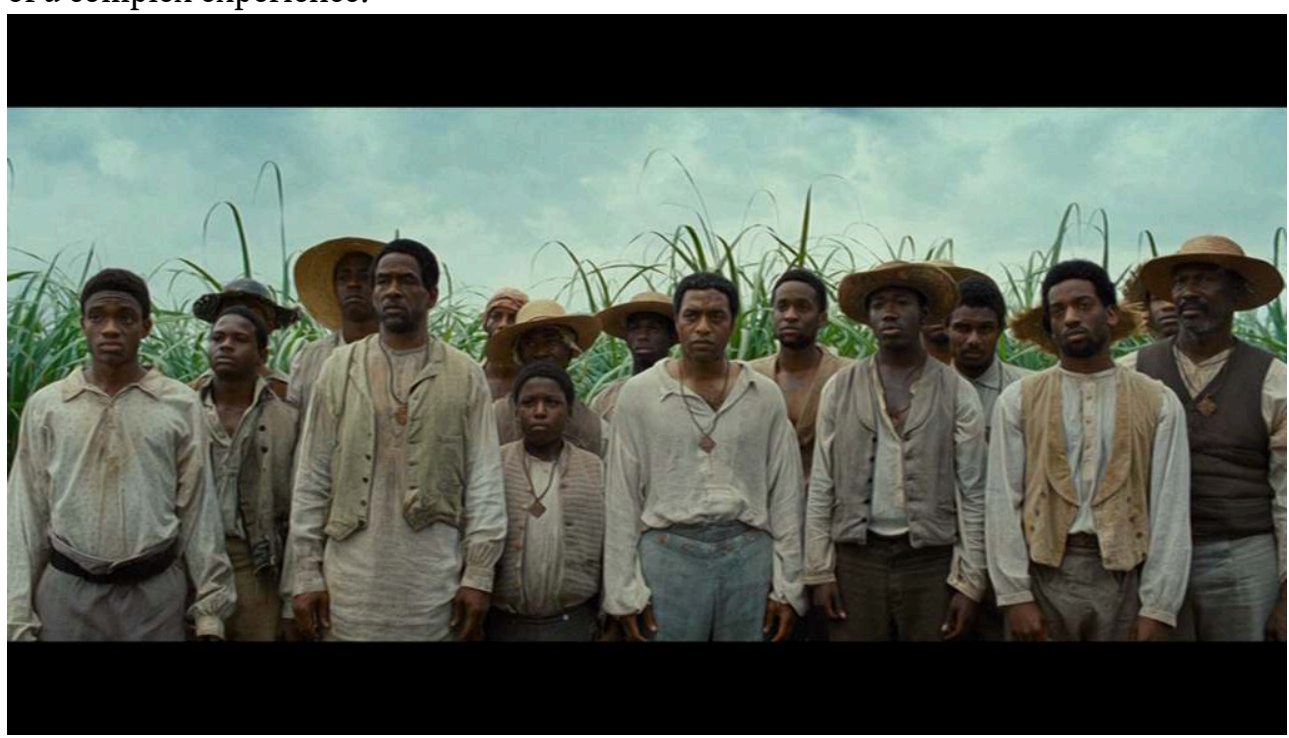


But these early snapshots recomposing new "blended" families quickly interact to form a wider patchwork telling numerous interrelated true stories. Most of the black and white figures McQueen represents on screen end up being full-fledged characters having firmly established roles in a fully developed plantation system. Once Northup has been transported south, the various figures of the plantation unit start to interplay and interact so that the activities and the mindsets of slaves and masters alike are foregrounded. The geographical concentration of the enslaved men and women on the various plantations does not reflect homogenization in their representation, but instead further complicates the slave experience. It highlights for instance slave hierarchies in the plantation culture and the addiction of some masters to their black sex slaves or concubines.

In 12 Years a Slave the visual and aural shock is so powerful that the debate over placing the black body at the center of the frame is displaced by that of constructing an authentic environment and narrative arc. What the director seems most intent on achieving is, as he told a film critic, "to present this as the life that people lived, and twist it" (quoted in Thaggert 332). The film's first intertitle against a black background - "This film is based on a true story"-is the exact opposite of a disclaimer clause. Everything the director purports to inscribe on screen derives from bona fide sources and therefore fits part of the definition of the biopic, which is to be based on the biography or portions of a historical person's biography. But contrary to the classic division between "the pre-war biopic [which] tends to address its spectators as citizens [and] the post-war biopic [which] tends to address its spectators as consumers of popular culture" (Neale 54), 12 Years a Slave first and foremost addresses the viewers as fully aware and responsible citizens.

\section{Blackness visible}

McQueen claims to cling to an authenticity which implies recoding Northup's 1853 autobiographical narrative into a new set of signs and conventions, as well as a nonglossed-over visual inscription of slavery. As a result, he positions himself beyond debates over truth and falsehood, and sets out to bring about catharsis. Through the prism of film, he makes the viewers intimately touch on the reality of slavery, however briefly. To some extent, this runs contrary to the general goal of the classic biopic: dramatizing the lifelong journey of a historically-based individual it ends up glorifying. As he mines the more recent formula of the "slice of life" biopic by focusing on Northup's time as a slave, McQueen circumvents not only the Great White Male narrative, a vehicle of the dominant reactionary or conservative ideology, but the Great Black Male narrative as well. The multiplicity of viewpoints, especially of African American protagonists in a genre film-one in which "generic identification becomes a formative component of film viewing" (Altman 277)-then further complicates the issue. Does McQueen productively question how media can make apparent the incoherence and fragmentation of relatively recent real events in American history? And in the wake of four hundred years of slavery, what strategies does he adopt to inscribe both historical facts and fictional narratives on screen in a cohesive and coherent ensemble? Very early on his goal was to help the readers and spectators experience difference and similarity between two sign systems through intersemiotic 
transposition. Even when reading the book, he was already obsessed by the actual inscription of "those [unadulterated] images" on screen:

Seeing the images. All I wanted to do was see those images. That has always been the power for me. Seeing those images. When I read the book, I wanted to see those images. Slavery is like the elephant in the room, and what you do is sprinkle flour over it and make it visible. We have to confront this topic in a real way. No one's blind anymore. No excuses. That's the power of cinema. (Gates 188)

With Northup's reverse trajectory from freedom to slavery and back to freedom, the usual framework of the slave narrative is inverted but also directly questioned as the un-sanitized depiction of slavery causes two time periods to overlap. The contemporary filmgoer's view of the "peculiar institution" is fundamentally defamiliarized and reshaped as there is

an uneasy temporal juxtaposition between the historical moment depicted graphically in the film and a belief that the type of racial inequality once institutionalized by slavery in the nineteenth century, then legally removed in the twentieth, is now completely and fully eradicated in the twenty-first. (Thaggert 333)

Such a strategy of disjunction and yet proximity between time periods literally and metaphorically plays with focal distance and generates viewer discomfort. Destabilizing the spectator entails focusing on individuated blacks whose complicated life stories interact with whites'. The shapes pain and suffering take in both communities are inscribed on screen in a singularly intense way. Each time, pain is literally embodied in flesh. Whether it be female or male pain, McQueen's camera gets as close as possible to the suffering subject, at times capturing only part of his or her tortured body within the frame or filming for an excruciatingly long time a scene of near-lynching or whipping.

In 12 Years a Slave, each disturbing "snapshot" fully extends into a scene or sequence which creates "cinematic discomfort" by "manipulating [the] representation of time and duration" (Thaggert 334). McQueen compels the viewer to take in the centrality of the black body as it is both being subjugated and asserting agency and rebellion. From this point of view, the two unusually long scenes of Northup's near-lynching and Patsey's (Lupita Nyong'o) flogging participate in testing representational limits. With such an insistent showing mode, it is no longer possible to accommodate violence, nor is looking away an option. The visual experience of slavery McQueen imposes on the spectator is all the more inescapable as he consistently uses the key trope of violence in new ways. Close-ups of body parts like Northup's feet barely touching the ground become powerfully metonymic of the whole person fighting "to survive," as Northup tells Eliza (Adepero Oduye). They circumvent any temptation to fetishize black visibility and suffering. They become the symptoms of some greater narrative arc that we have to follow to the end and which bridges the gap with today's supposedly postracial America. 


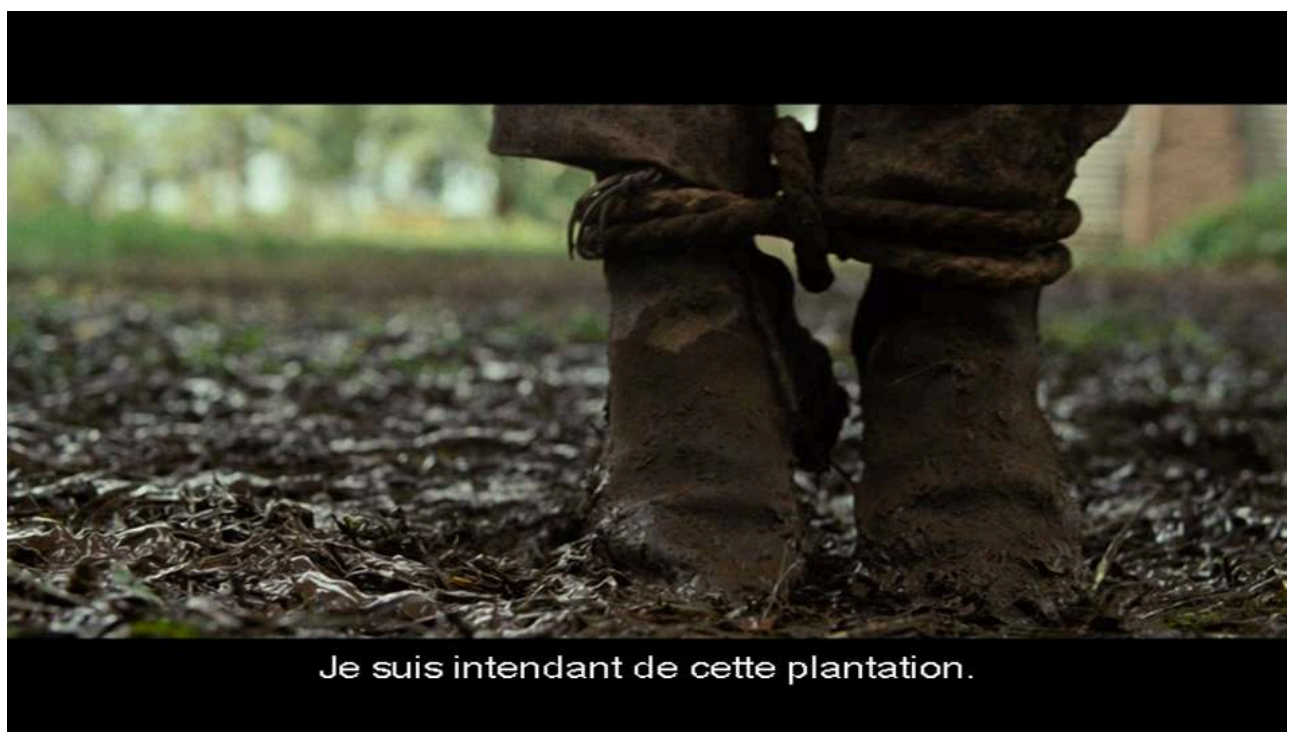

15 Miriam Thaggert underlines the way in which 12 Years a Slave captures how Americans became accustomed to the violence of slavery and draws a parallel with how they explore today's racial subtext or confront head-on some overtly problematic racial content:

His representation charts the desensitization to violence in antebellum America; and [...] the reactions to his film may suggest an increasing numbness, or tolerance, for subtle forms of discrimination in our own supposedly postrace America. (Thaggert 334)

The entire virtually silent scene uncompromisingly inscribes on screen the visual shock of the "photographs and postcards taken as souvenirs at lynchings throughout America" that collector James Allen uncovered while searching through the nation's past. His book Without Sanctuary, which came out in 1994, has since then been reissued several times and has given rise to the much-accessed website "Without Sanctuary" complete with photos and a forum.

16 McQueen and Northup before him rework some of the classic tropes of African American culture. When focusing on enslaved black women, racial desirability and its devastating consequences are no longer exclusively connected to the figures of the tragic mulatta or the disposable "comfort girl." The fatal attraction Patsey exerts on Epps (Michael Fassbender) actually gives rise to a long analysis of the young girl's frame of mind and behavior which prevents the inscription of heavily stereotyped representations of black mistresses and white masters. The staging of the relationship between black sex slave and white master materializes on screen not so much another development of the great white narrative as an in-depth analysis of the girl's own feelings of entrapment and desperation. The sections of the film relating to Patsey indeed operate as yet another peculiar biopic. In these sequences, the biopic stops being "differential in the role it assigns to gender" (Custen 3) and reworks the classic black archetypal figure of the Tragic Woman. Patsey is a "historical person" in her own right (Custen 5). She also becomes the focus of the biographical film which is consistently "minimally composed of the life, or the portion of a life, of a real person whose real name is used" (Custen 6) even though she is neither a mulatta nor a bereft mother whose children have been sold away like Eliza. ${ }^{3}$ Along with the latter, Patsey epitomizes a tragic facet of the objectified and brutalized woman while telling a very personal story. The crude scenes of sexual intercourse 
between master and slave never achieve any degree of intimacy. Paradoxically, the most intimate moments are those when the young girl is playing, oblivious to her surroundings, and making corn husk dolls. McQueen's camera frames Patsey lost in the wonder world of childhood, sometimes only partly registering on screen as entire portions of her secret self and life cannot be captured and thus have to remain off screen.

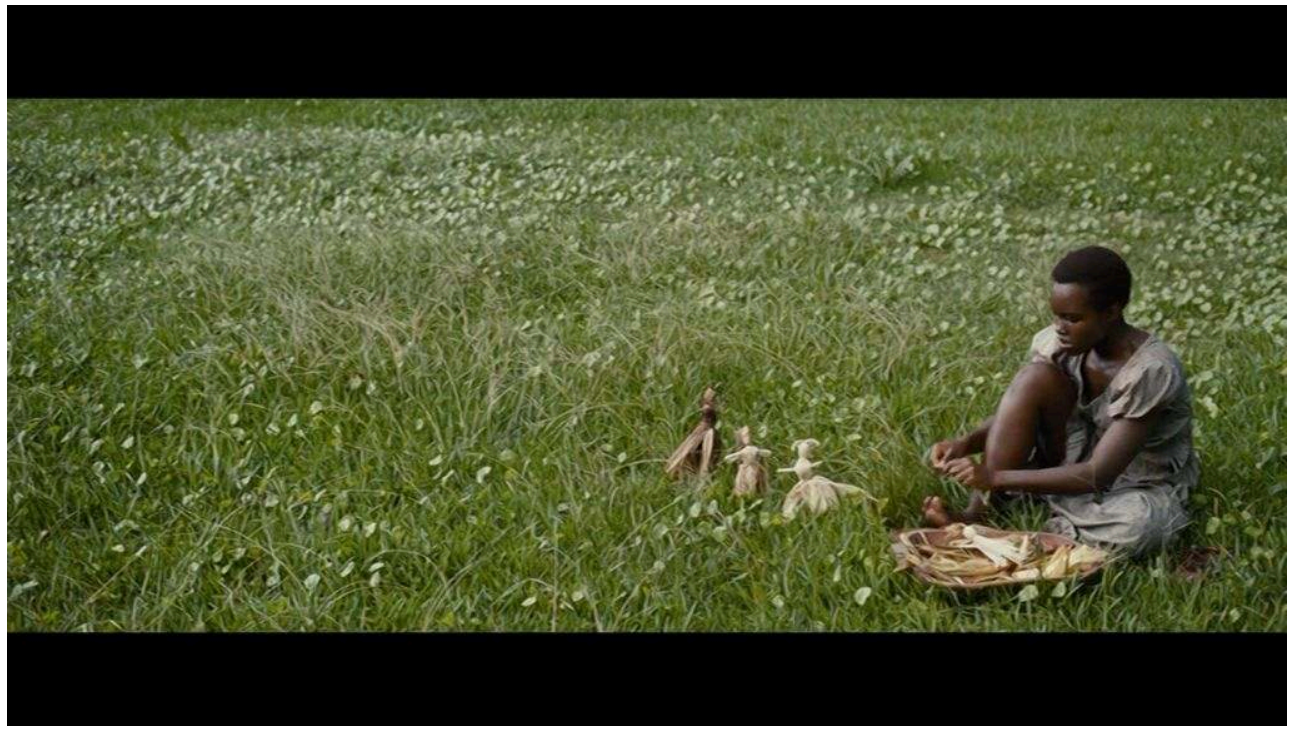

McQueen alternates shots focusing on Patsey's ravaged body being manipulated and violated by the white masters, both male and female, and shots of the young girl asserting her own subjectivity and selfhood as when trying to convince Northup that he should end her life or coming up with strong arguments for Epps not to flog her.

Hence the visual inscription of pathos and horror alternates with the materialization of self-assertion even if the final shot of Patsey is that of a small figure receding in the background as Northup is extracted from the plantation world. As he leaves behind the slave's subhuman status, the camera captures him stepping up into the horse carriage on his way to regain his former identity and reintegrate his own New York state community.

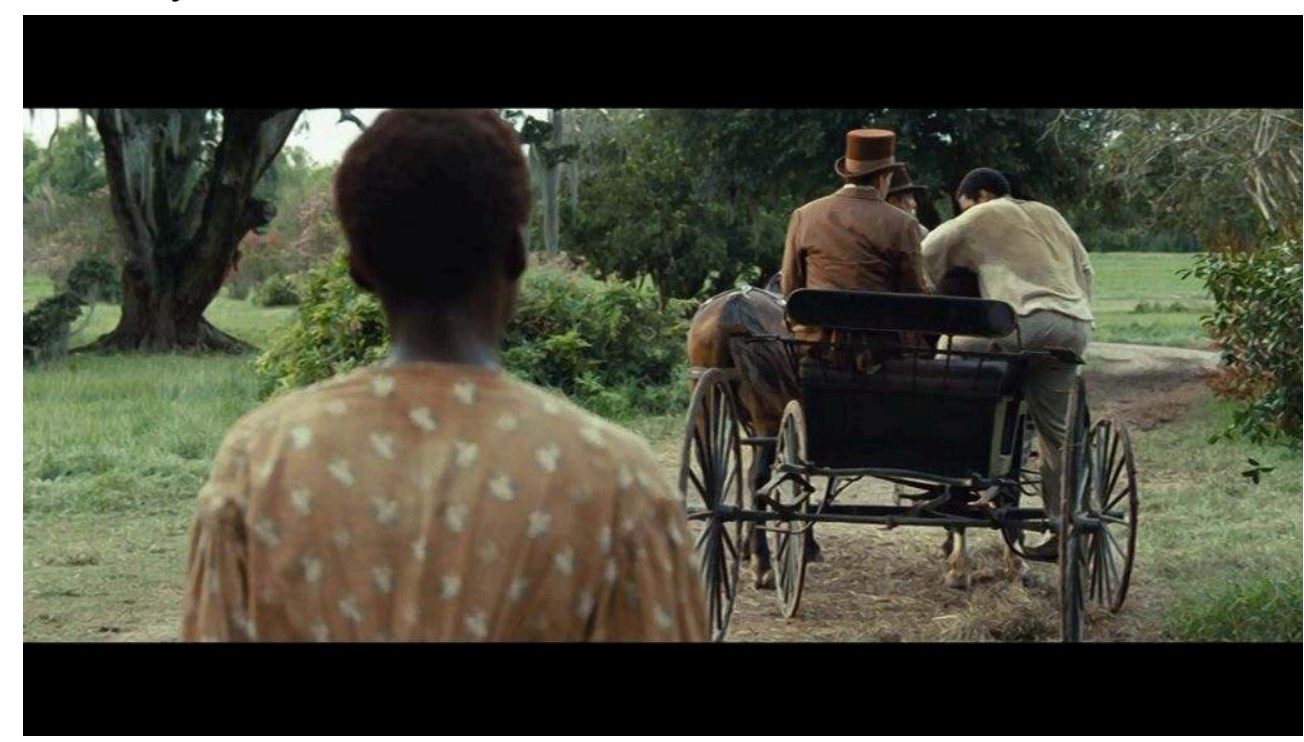




\section{Shock corridor: impossible closure?}

19 After viewing the film for the first time at the Paris press screening in 2014, members of the audience were left speechless. We had just emerged from what Samuel Fuller once called a "shock corridor" (Shock Corridor, 1963) and felt compelled to remain silent, before eventually comparing the forceful impact of the movie with Richard Fleisher's Mandingo (1975) among other films. The tagline of Fleisher's film was "Expect the Truth," and at the time he was one of the very few American moviemakers willing to confront race and slavery in a realistic way (Paquet-Deyris, 2014).

McQueen chooses a similar approach but he also further plays on the conventional tropes of African American culture. He revisits the classic definition and motifs of the biopic to make blackness visible in a contemporary Hollywood film and a context of white-controlled mass media organizations. Mediating Northup's literary source, he turns it into a central filmic text imposing on the viewer a methodology to foreground underrepresented black bodies, experiences, and histories. He thus promotes a new kind of American national identity bypassing the frequent critical comment that "Blacks appear less individuated, more homogeneous [as] film reinforces Whites' ignorance of Blacks' variety and humanity" (Entman and Rojecki 182). According to some critics, in order to come up with rich and complex ethnic and racial representations on screen, he sometimes overdoes the self-conscious capture of the past. Jim Down's reaction is also typical of the type of visceral reactions the movie generated:

Unlike other films, or even books for that matter, that have the ability to transport me to another time and place, that make me forget that I am sitting in a movie theater, 12 Years a Slave did not achieve that level of literary, imaginative migration. Instead I could feel the director's, screenwriters', and actors' efforts to so selfconsciously capture the past. (Miller 313)

But through the emphasis on violence, the director, screenwriter, and cast allow the movie to clearly materialize what Toni Morrison calls "Unspeakable Things Unspoken" (Morrison), fully disclosed on a global scale.

\section{BIBLIOGRAPHY}

ALLEN, James, ed. Without Sanctuary: Lynching Photography in America. Santa Fe: Twin Palms, 2000.

ALTMAN, Rick. Film/Genre. London: BFI Publishing, 1999.

ANDREWS, William L., and Henry Louis GATES, Jr., eds. Slave Narratives. New York: Library of America, 2000.

BINGHAM, Dennis. Whose Lives Are They Anyway? The Biopic as Contemporary Film Genre. New Brunswick: Rutgers University Press, 2010.

CUSTEN, George F. Bio/Pics: How Hollywood Constructed Public History. New Brunswick: Rutgers University Press, 1992. 
ENTMAN, Robert M., and Andrew ROJECKI. The Black Image in the White Mind: Media and Race in America. Chicago: University of Chicago Press, 2001.

GATES, Henry Louis, Jr. “12 Years a Slave: A Conversation with Steve McQueen.” Transition, no. 114,2014 , p. $185-196$.

KAPLAN, H. Roy. The Myth of Post-Racial America: Searching for Equality in the Age of Materialism. Lanham: Rowman \& Littlefield, 2011.

LEONARD, David J., and Lisa A. GUERRERO, eds. African Americans on Television: Race-ing for Ratings. Santa Barbara: Praeger, 2013.

MILLER, Brian Craig. "Film Roundtable: 12 Years a Slave." Civil War History, vol. 60, no. 3, 2014, p. 310-336.

MORRISON, Toni. "Unspeakable Things Unspoken: The Afro-American Presence in American Literature.” Michigan Quarterly Review, vol. 28, no. 1, 1989, p. 1-34.

NEALE, Steve. Genre and Hollywood. London: Routledge, 2000.

NORTHUP, Solomon. Twelve Years a Slave: Narrative of Solomon Northup, a Citizen of New-York, Kidnapped in Washington City in 1841, and Rescued in 1853, from a Cotton Plantation Near the Red River, in Louisiana. Auburn: Derby and Miller, 1853.

PAQUET-DEYRIS, Anne-Marie. “Autour du film 12 Years a Slave de Steve McQueen.” France Culture, 25 January 2014. Accessed 26 August 2019.

PAQUET-DEYRIS, Anne-Marie. “Glorious Bastards in Tarantino's Django Unchained: When the West Crosses the South." Critical Perspectives on the Western: From a Fistful of Dollars to Django Unchained. Ed. Lee Broughton. Lanham: Rowman \& Littlefield, 2016, p. 153-166.

ROY, Michaël. Textes fugitifs. Le récit d'esclave au prisme de l'histoire du livre. Lyon: ENS Éditions, 2017.

TAUSSIG, Michael. Defacement: Public Secrecy and the Labor of the Negative. Stanford: Stanford University Press, 1999.

THAGGERT, Miriam. “12 Years a Slave: Jasper’s Look.” American Literary History, vol. 26, no. 2, 2014, p. 332-338.

TILLET, Salamishah. “'I Got No Comfort in This Life': The Increasing Importance of Patsey in 12 Years a Slave.” American Literary History, vol. 26, no. 2, 2014, p. 354-361.

ZINSSER, William, ed. Inventing the Truth: The Art and Craft of Memoir. Boston: Houghton Mifflin, 1998.

\section{NOTES}

1. On Django Unchained, see Paquet-Deyris, 2016.

2. In McQueen's earlier movies Hunger (2008) and Shame (2011), the body is a symptom, the product of some ailing condition. To a certain extent, Micheaux also used it as a visual sign of dysfunction and exclusion from the white normative world. In Within Our Gates (1920), the scene in which the young mulatta is almost raped by her white father is a direct answer to the racist scene of the attempted rape of Flora Cameron (Mae Marsh) by black soldier Gus (Walter Long) in D.W. Griffith's The Birth of a Nation (1915). It also exposes historical truth about black/white relationships in an uncompromising way. 
3. Hélène Charlery makes the case for the central role of Patsey in 12 Years a Slave in her contribution to this issue.

\section{ABSTRACTS}

In his successful 2013 cinematic release 12 Years a Slave, Steve McQueen circumvents the "great white narrative" by addressing race "head-on" instead of metaphorically, writing every character within their own racial background. As in Solomon Northup's 1853 Twelve Years a Slave, black characters are not removed from their own histories; instead, they are shaped and defined by them. To what extent, then, does the film distinctly voice racial concerns and tensions, and provide representational spaces on screen in a nuanced and reflective manner? How does it-if indeed it does-subvert the standard black slave/character and white master/hero dynamic, and embrace a wide variety of black stories and perspectives? By reconsidering the classic biopic/ historical film, this article examines how the movie relocates America's problems with race at the very heart of the national debate and offers a "post-post-racial" screen model that directly confronts race history.

Dans son film à succès 12 Years a Slave (2013), Steve McQueen contourne le grand récit blanc en abordant directement et non plus métaphoriquement la notion de race, et en réinscrivant chaque personnage dans son propre contexte racial. Tout comme dans le récit autobiographique de Solomon Northup (Twelve Years a Slave, 1853) à l'origine du film, les personnages noirs ne sont pas construits indépendamment de leur histoire, mais bien modelés et définis par celle-ci. Jusqu'à quel point le film donne-t-il voix aux questions et tensions raciales et offre-t-il de manière nuancée et réflexive un espace de représentation à l'écran? De quelle façon subvertit-il - si tel est bien le cas - la dynamique narrative conventionnelle entre esclave/personnage noir et maître/héros blanc? Comment parvient-il à intégrer un large spectre d'histoires et de perspectives spécifiquement noires? En revenant sur les contours du biopic et du film historique classique, cet article montre de quelle façon le film réinsère au cœur même du débat national la relation conflictuelle de l'Amérique à la notion de race et convoque un modèle "post-postracial » qui intègre pleinement l'histoire raciale du pays.

\section{INDEX}

Keywords: 12 Years a Slave, Steve McQueen, slavery, race, slave narrative

Mots-clés: 12 Years a Slave, Steve McQueen, esclavage, questions raciales, récit d'esclave

\section{AUTHOR}

\section{ANNE-MARIE PAQUET-DEYRIS}

Université Paris Nanterre 